GLOBAL WATER PATHOGEN PROJECT

PART FIVE. CASE STUDIES

\title{
HOW DO I ENSURE MY EXISTING RECYCLED WATER SCHEME IS SAFE?
}

Annalisa Contos

Atom Consulting

Sydney, Australia

Natalie Crawford

Atom Consulting

Sydney, Australia 


\section{Copyright:}

\section{cc) (1) (2) \\ BY SA}

This publication is available in Open Access under the Attribution-ShareAlike 3.0 IGO (CC-BY-SA 3.0 IGO) license (http://creativecommons.org/licenses/by-sa/3.0/igo). By using the content of this publication, the users accept to be bound by the terms of use of the UNESCO Open Access Repository (http://www.unesco.org/openaccess/terms-use-ccbysa-en).

\section{Disclaimer:}

The designations employed and the presentation of material throughout this publication do not imply the expression of any opinion whatsoever on the part of UNESCO concerning the legal status of any country, territory, city or area or of its authorities, or concerning the delimitation of its frontiers or boundaries. The ideas and opinions expressed in this publication are those of the authors; they are not necessarily those of UNESCO and do not commit the Organization.

\section{Citation:}

Crawford, N. and Contos, A. (2019). How do I ensure my existing recycled water scheme is safe? In: J.B. Rose and B. Jiménez-Cisneros, (eds) Water and Sanitation for the 21st Century: Health and Microbiological Aspects of Excreta and Wastewater ManagementGlobal Water Pathogen Project. (S. Petterson and G. Medema (eds) Part 5: Case Studies), Michigan State University, E. Lansing, MI, UNESCO. https://doi.org/10.14321/waterpathogens.76

Acknowledgements: K.R.L. Young, Project Design editor; Website Design: Agroknow (http://www.agroknow.com)

Last published: May 13, 2019 


\section{Summary}

\section{Highlights}

- An application of the Australian Guidelines for Wastewater Recycling (2006) is presented

- Recycled water is used for irrigation of food crops and public space

- The approach demonstrates how to assess and improve recycling system safety

- Surrogates were used to estimate pathogen removal of treatment barriers

- Bacterial and protozoan surrogate testing showed insufficient treatment

- Operational chlorine targets and on-site audits were implemented

\section{Management objective}

The objective of this case study was to determine whether public health risks from the local government operated recycled water scheme were appropriately managed through treatment and non-treatment barriers (end user controls), specifically to:
- Determine the pathogen $\log _{10}$ reduction requirements for recycled water applied for a mix of uses including food crop and municipal irrigation.

- Verify the four recycled water plants were meeting these requirements and the non-treatment barriers (end user controls) were adequate.

\section{Location and setting}

The project took place in the mid north coast of NSW, Australia. Due to historical community pressure against ocean discharge an extensive reuse scheme was developed utilising the effluent from four sewage treatment plants. All plants have primary screening, biological treatment (using an oxidation ditch and clarifier on one plant, and intermittent aeration in the other three). UV and chlorination was used as disinfection in one plant, chlorine in two others and a tertiary maturation pond for the final plant. This recycling scheme now supporting a range of horticultural industries including blueberries, banana and greenhouses for tomatoes and cucumbers. These industries may not have a potable water connection to the town supply. The council (local government), which operates the treatment plants also uses the water to irrigate sports fields and plant nurseries. The region is culturally and linguistically diverse; seasonal workers may be used during harvest.

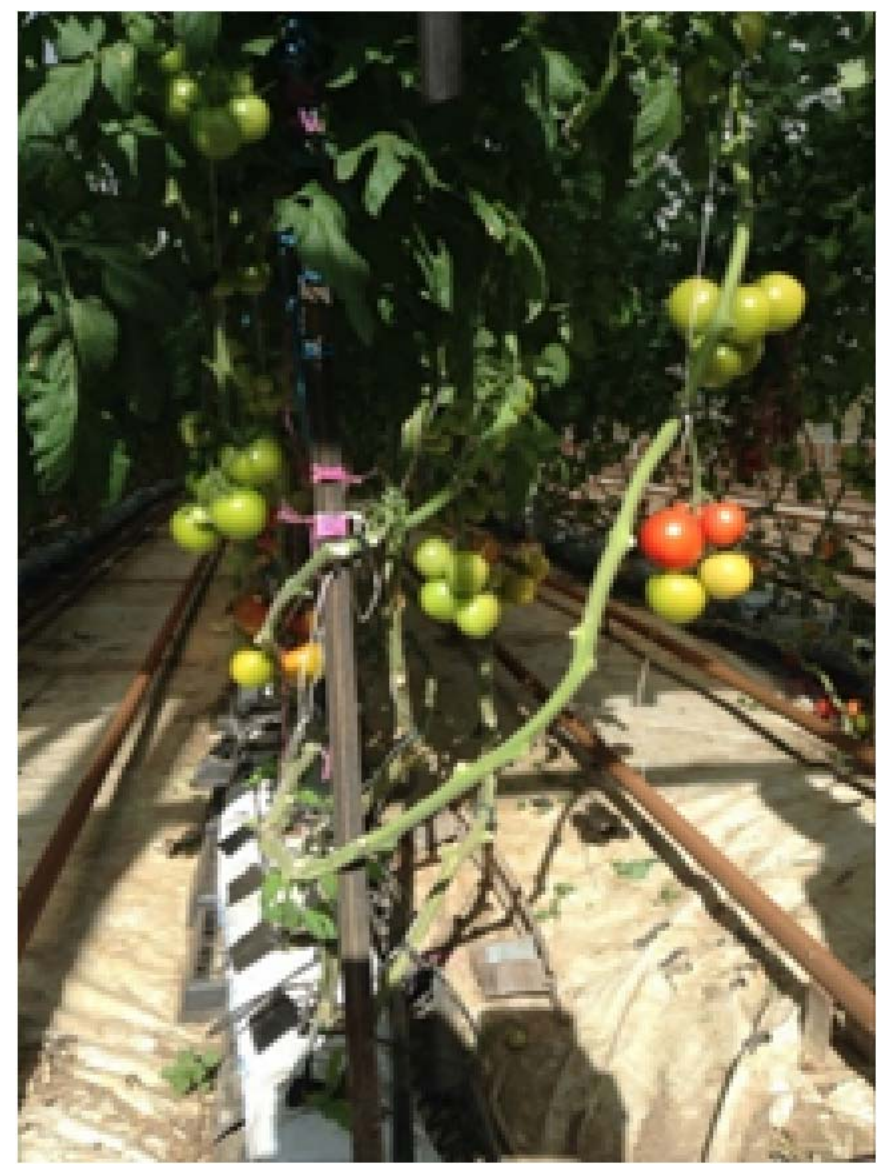

Figure 1. Drip irrigation of tomatoes (photo provided by Annalisa Contos) 


\section{Description of the system}

The pathogen $\log _{10}$ requirements for each of the recycled water uses was established using the default values in the AGWR (2006; GWPP case study Australian guidelines for water recycling), considering exposure to food consumers, facility workers and nearby community as appropriate. The AGWR (2006) provide default $\log _{10}$ credits for non-treatment barriers such as $3 \log _{10}$ reduction for drip irrigation of crops with no ground contact.

Initial process unit verification was conducted using $E$. coli as a surrogate for bacterial pathogen removal and Clostridium perfringens as a process surrogate for Cryptosporidium. Initial C. perfingens LRVs were lower than expected for the UV unit. We realised this was because $C$. perfringens requires a significantly higher UV dose than Cryptosporidium (Smeets et al., 2006). E. coli requires a similar UV dose as Cryptosporidium so was used as the process surrogate for UV.

Surrogate virus testing was not undertaken due to both cost and difficulties in ensuring the samples reached a suitable laboratory in time for analysis. Chlorination targets (C.t) were quantified to ensure sufficient disinfection of virus and bacteria.

\section{Outcome and recommendations}

- Reference pathogen $\log _{10}$ reduction targets to achieve safety were calculated

- Reclaimed water treatment plant $\log _{10}$ reductions were verified

- Non-treatment barriers such as drip irrigation were necessary to ensure public health risk were managed for these systems. The sample of audits undertaken demonstrated regular end user education and audits are essential to ensure these barriers are in place and remain effective.

- Chlorination targets at the treatment plants were increased to ensure sufficient disinfection of virus and bacteria.

\section{Implications for practioners}

This project demonstrates how to assess and improve the safety of existing recycled water plants. Plant verification using a combination of indicator organisms and desktop calculations can determine if the water is suitable for the end uses. From this, action plans incorporating short term operational changes (such as increasing chlorination), end user engagement (education and audit) and longer term infrastructure improvements can be implemented to improve water safety.

\section{Problem formulation}

The purpose of the case study was to determine whether public health risks from the existing recycled water scheme were appropriately managed.

The scope of the assessment included:

- Determine the pathogen $\log _{10}$ reduction requirements for recycled water applied for a mix of uses including food crop and municipal irrigation.

- Verify the four recycled water plants were meeting these requirements and that the non-treatment barriers (end user controls) were adequate.

\section{What are the end use water quality requirements?}

The pathogen $\log _{10}$ requirements (bacteria, virus and protozoa) for each of the recycled water end uses was established using the default values in the AGWR (2006), considering exposure to food consumers, facility workers and nearby community as appropriate. The default assumptions detailed in the AGWR were tested for each end use type. For example, did the uses of the water means pathogen reductions beyond the municipal $\log _{10}$ requirements were required. The AGWR calculates tolerable risk for $10^{-6}$ DALYs per person per year, with assumptions on exposure volumes, frequency of exposure and the pathogens present in the source water. The number of times people are exposed under the municipal irrigation end use category were tested and deemed applicable for the sports field in use.

Table 1. Recycled Water Scheme Log10 reduction requirements by pathogen group

\begin{tabular}{lccc}
\hline End Use & Bacteria & Viruses & Protozoa \\
\hline Municipal irrigation (sports fields) & 4.0 & 5.2 & 3.7 \\
$\begin{array}{l}\text { Commercial food crops (bananas, tomatoes, } \\
\text { blueberries) }\end{array}$ & 5.0 & 6.1 & 4.8
\end{tabular}




\section{Does treatment meet the end use requirement?}

Total required pathogen $\log _{10}$ reduction reductions values were calculated for each recycled water scheme based on the AGWR (2006) default values (for example, secondary treatment has an indicative $\log _{10}$ reduction of 1.0-3.0 for bacterial pathogens).

Process unit verification was undertaken to verify the theoretical AGWR (2006) default values. E. coli was used as a surrogate for bacterial pathogen removal and Clostridium perfringens as a process surrogate for Cryptosporidium. Chlorination targets (C.t) were quantified to ensure sufficient disinfection of virus and bacteria. The free chlorine level to achieve a 4-log reduction for viruses was calculated for recycled water treatment plant, based on achieving a chlorine contact time for coxsackie B virus (Black et al. 2009; Keegan et al. 2012). These $\log _{10}$ reduction treatment values identified for each scheme were then compared see if end use requirements were being met.

\section{Are additional barriers need to meet requirements?}

Gaps in treatment $\log _{10}$ reduction requirements were then assessed against non-treatment barriers (e.g. end use controls). Non-treatment barriers were identified and assigned default $\log _{10}$ credits (AGWR 2006) for each exposure pathways (Table 2). A maximum of $3 \log _{10}$ reduction was used for end use controls.

Verification of non-treatment barriers was undertaken through representative site audits. The audits investigated if the non-treatment barriers were being effectively implemented.

Table 2. Recycled Water Scheme 1: Theoretical non-treatment barriers $\log _{10}$ reduction values

\begin{tabular}{|c|c|c|c|c|c|}
\hline $\begin{array}{c}\text { Non-Treatment } \\
\text { Barrier }\end{array}$ & $\begin{array}{c}\text { Is Exposure } \\
\text { Pathway } \\
\text { Affected? } \\
\text { (Consumption } \\
\text { of Produce) }\end{array}$ & $\begin{array}{c}\text { Is } \\
\text { Exposure } \\
\text { Pathway } \\
\text { Affected? } \\
\text { (Ingestion } \\
\text { of Spray) }\end{array}$ & Bacteria & Viruses & Protozoa \\
\hline $\begin{array}{l}\text { Drip Irrigation } \\
\text { of crops with } \\
\text { limited to no } \\
\text { ground contact } \\
\text { (e.g. tomatoes, } \\
\text { capsicums, } \\
\text { blueberries) }\end{array}$ & Yes & Yes & 3 & 3 & 3 \\
\hline $\begin{array}{l}\text { Removal of skins } \\
\text { from produce } \\
\text { before } \\
\text { consumption } \\
\text { (e.g. bananas) }\end{array}$ & Yes & No & 2 & 2 & 2 \\
\hline $\begin{array}{l}\text { No public access } \\
\text { during irrigation }\end{array}$ & No & Yes & 2 & 2 & 2 \\
\hline
\end{tabular}




\section{Understand the risks to human health}

To further understand the risk to human health from the recycled water scheme and how they were being managed, a risk assessment workshop was held with stakeholders. The risk assessment identified hazards, hazardous events and the barriers implemented to prevent exposure. Effectiveness of the treatment and non-treatment barriers was assessed to determine any areas in which risks to human health may be compromised.

\section{Outcomes}

Theoretical $\log _{10}$ credits for treatment barriers were reviewed for each recycled water scheme. Example results for Recycled Water Scheme 1 are shown in Table 3.

Table 3. Recycled Water Scheme 1: Theoretical treatment $\log _{10}$ reduction values

\begin{tabular}{cccc}
\hline & Bacteria & Viruses & Protozoa \\
\hline Primary Treatment & $0-0.5$ & $0-0.1$ & $0-0.5$ \\
Secondary Treatment & $1.0-3.0$ & $0.5-2.0$ & $0.5-2.0$ \\
UV Disinfection & & adenovirus \\
& $2.0-4.0$ & $1.0-4.0$ & $3.0-4.0$ \\
Chlorination & & other $3.0-4.0$ & $0-0.5$ \\
Sub-Total & $2.0-4.0$ & 4.0 & $3.5-7.0$
\end{tabular}

\section{Verification monitoring}

Three influent samples of $C$. perfingens and thirteen samples across process units were taken over a two-month period at each plant. The influent samples were consistent with the values provided in the AGWR. The median $C$. perfingens value was used within the analysis. $\log _{10}$ pathogen reduction values were calculated across each process step for each sample taken. The time the samples were taken did not account for hydraulic retention times. This resulted in a negative $\log _{10}$ pathogen reduction valueson one occasion.

Initial $C$. perfingens $\log _{10}$ reduction values were lower than expected for the UV process unit. It was realised that this was because $C$. perfringens requires a significantly higher UV dose than Cryptosporidium (Smeets et al., 2006). E. coli requires a similar UV dose as Cryptosporidium so was used as the process surrogate for UV. Surrogate virus testing was not undertaken due to both cost and difficulties in ensuring the samples reached a suitable laboratory in time for analysis (the minimum default AGWR value were used in this instance). A summary of verification results for recycled water scheme 1 is shown in Table 4.

For some of the treatment plants, primary and secondary treatment and chlorination processes on average, showed evidence of greater $\log _{10}$ reductions than the indicative values reported in the AGWR (2006). At one plant variability in $\log _{10}$ reduction for filtration indicated that process optimisation mav improve $\log _{1 n}$ reduction effi 
Table 4. Recycled Water Scheme 1: Treatment verification monitoring results

\begin{tabular}{|c|c|c|c|c|}
\hline & Indicator & Surrogate & $\begin{array}{c}\text { Sample } \\
\text { Location }\end{array}$ & $\begin{array}{c}\log _{10} \\
\text { reduction } \\
\text { values } \\
\text { (LRV) }\end{array}$ \\
\hline $\begin{array}{c}\text { Primary and } \\
\text { Secondary } \\
\text { Treatment }\end{array}$ & Protozoa & $\begin{array}{c}C . \\
\text { perfringens }\end{array}$ & $\begin{array}{c}\text { Influent } \\
\text { and } \\
\text { before } \\
\text { filter }\end{array}$ & 1.5 \\
\hline Filtration & Protozoa & $\begin{array}{c}\text { C. } \\
\text { perfringens }\end{array}$ & $\begin{array}{c}\text { Before } \\
\text { UV }\end{array}$ & 0 \\
\hline UV & Bacteria, & & $\begin{array}{c}\text { Before } \\
\text { UV and } \\
\text { After UV }\end{array}$ & 2.0 \\
\hline
\end{tabular}

Chlorination targets at the treatment plants were increased to ensure sufficient disinfection of virus and bacteria. A summary of treatment $\log 10$ reduction values is shown in Table 5 .

Table 5. Recycled Water Scheme 1: Treatment $\log _{10}$ reduction values

\begin{tabular}{|c|c|c|c|}
\hline & Bacteria & Viruses & Protozoa \\
\hline Primary Treatment & $0^{\mathrm{b}}$ & $0.0^{\mathrm{b}}$ & $1.5^{\mathrm{a}}$ \\
\hline Secondary Treatment & $1^{\mathrm{b}} 0^{\mathrm{b}}$ & $0.5^{\mathrm{b}}$ & \\
\hline Filters With Coagulation & $0^{\mathrm{b}}$ & $0.0^{\mathrm{b}}$ & $0.0^{\mathrm{a}}$ \\
\hline UV Disinfection & $2.0^{\mathrm{a}}$ & $1.0^{\mathrm{b}}$ & $2.0^{\mathrm{a}}$ \\
\hline Chlorination & $4.0^{\mathrm{C}}$ & $4.0^{\mathrm{c}}$ & $0.0^{\mathrm{c}}$ \\
\hline Sub-Total & 7.0 & 5.5 & 3.5 \\
\hline $\begin{array}{c}\text { Comparison With Municipal Irrig } \\
\text { Requirements }\end{array}$ & +3.0 & +0.3 & -0.2 \\
\hline $\begin{array}{c}\text { Comparison With Commercial Foc } \\
\text { Requirements }\end{array}$ & +2.0 & -0.6 & -1.3 \\
\hline
\end{tabular}

Notes:

${ }^{a}$ Derived from verification monitoring (Table 4)

${ }^{\mathrm{b}}$ Derived from minimum range of published theoretical values (Table 2)

${ }^{c}$ Values derived from chlorine contact time calculations, assuming chlorine contact times are met through the implementation of chlorination critical limits

A comparison of $\log _{10}$ reduction values against end use water quality requirements found that non-treatment barriers (such as drip irrigation) were necessary to ensure the public health risk were managed for all the schemes. Example graphs of protozoan treatment $\log 10$ reduction values are shown in Figure 2. 

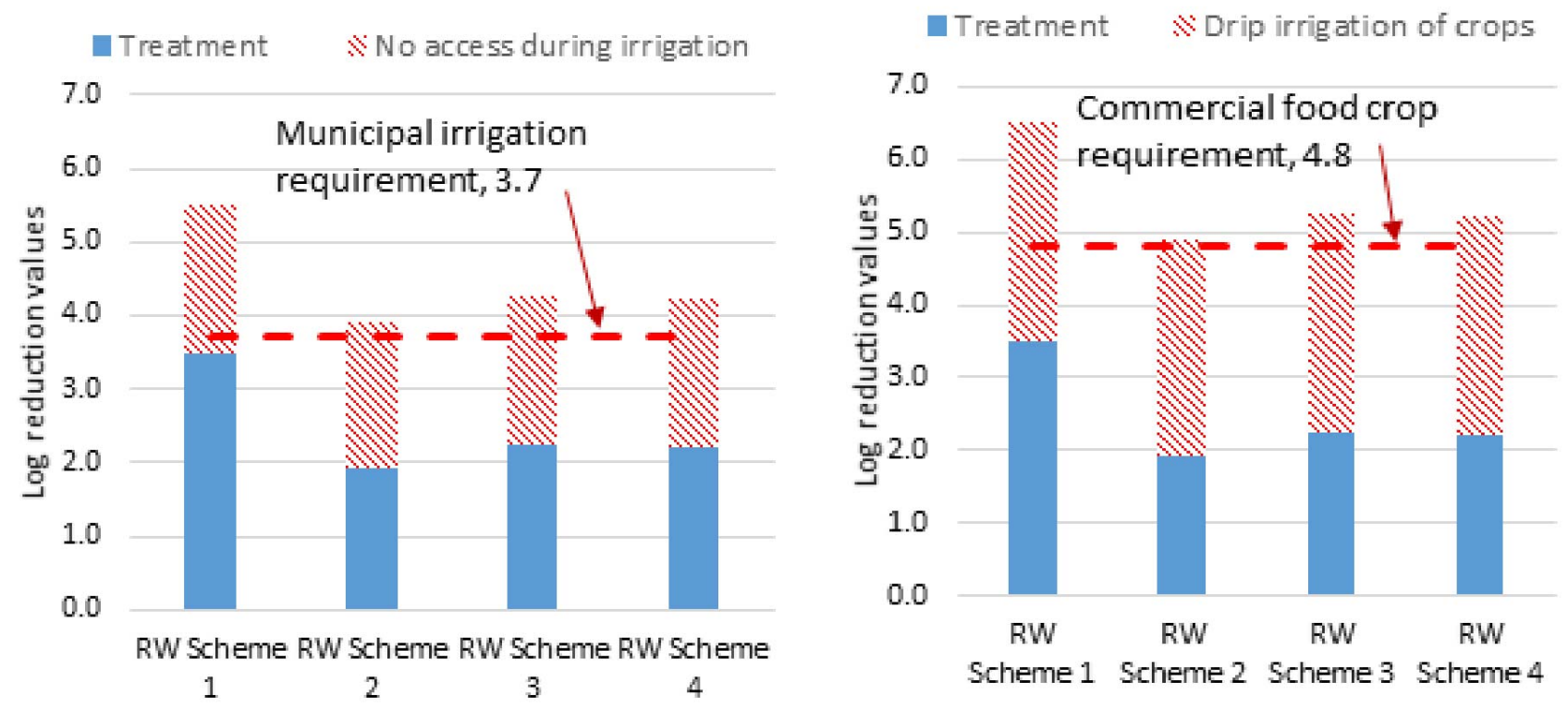

Figure 2. Example protozoan pathogen treatment and non-treatment barriers and end-user requirements (figure provided by Atom Consulting with permission)

\section{Risk assessment}

The risk assessment workshop reviewed and assessed the adequacy of treatment and non-treatment barriers to prevent significant hazards from the recycled water system. The workshop identified where additional barriers, process optimisation, additional maintenance and/or increased end user training was needed. In particular, it was recommended that audits be undertaken to ensure that non-treatment barriers are being effectively implemented.

\section{Implications for practitioners}

Adequacy of implementation of non-treatment (end use) barriers was identified as a key issue for this scheme. A transient worker population at the end use sites means that training (in the form of workplace inductions) must be ongoing. Appropriate governance, in the form of end user agreements are key to ensuring that end users successfully implement the required controls, both operationally and in support areas (e.g. training and maintenance). An auditing scheme undertaken by the council is essential in order to verify that there is end user compliance and ongoing awareness of scheme hazards and the potential risk to human health. Consideration should also be given to appropriately documenting approved end use types and strategies for assessing changes to future end use types.
Treatment verification using a combination of indicator organisms and desktop calculations can determine if the water is suitable for the end uses. Verification monitoring should be undertaken that is appropriate to the treatment processes in place and with consideration given to the financial costs of tests, using data available in the literature where appropriate. Verification testing can identify areas where process optimisation or longer-term infrastructure improvements can be implemented to improve water safety.

\section{Implication for risk management}

This project demonstrates how to assess and improve the safety of existing recycled water plants within the context of the AGWR(2006). Existing recycled water schemes while designed to meet chemical water quality standards may not have been designed for pathogen reduction.

Successful risk management includes having access to accurate and appropriate information regarding how the scheme is being implemented in practice. Appropriate stakeholders are needed for input into the risk assessment process. Existing schemes may no longer be operated as per the original design. Operational knowledge is essential in understanding how processes work when assessing the effectiveness of barrier implementation. On site verification of the treatment process and end user sites is essential. 


\section{References}

Smeets, P., Rietveld, L., Hijnen, W., Medema, G. and Stenström, T.A. (2006). Efficacy of water treatment processes. Microbiological risk assessment: a scientific basis for managing drinking water safety from source to tap. MicroRisk Final Report. pp. 70. 